\title{
Gut/Oral Bacteria Variability May Explain the High Efficacy of Green Tea in Rodent Tumor Inhibition and Its Absence in Humans
}

\author{
Guy R. Adami ${ }^{1, * \mathbb{C}}$, Christy Tangney $^{2}{ }^{\mathbb{D}}$, Joel L. Schwartz ${ }^{1}\left(\mathbb{D}\right.$ and Kim Chi Dang ${ }^{1}$ \\ 1 Department of Oral Medicine \& Diagnostic Sciences, Center for Molecular Biology of Oral Diseases, \\ College of Dentistry, University of Illinois at Chicago, 801 South Paulina Street, Chicago, IL 60612, USA; \\ joschwar@uic.edu (J.L.S.); kimchidang15@gmail.com (K.C.D.) \\ 2 Department of Clinical Nutrition, College of Health Sciences, Rush University Medical Center, \\ 600 South Paulina St, Room 716 AAC, Chicago, IL 60612, USA; Christy_Tangney@rush.edu \\ * Correspondence: gadami@uic.edu; Tel.: +1-312-996-6251
}

Academic Editors: Adam Jurgoński, Bartosz Fotschki and Tomasz Sawicki Received: 16 September 2020; Accepted: 12 October 2020; Published: 16 October 2020

\begin{abstract}
Consumption of green tea (GT) and GT polyphenols has prevented a range of cancers in rodents but has had mixed results in humans. Human subjects who drank GT for weeks showed changes in oral microbiome. However, GT-induced changes in RNA in oral epithelium were subject-specific, suggesting GT-induced changes of the oral epithelium occurred but differed across individuals. In contrast, studies in rodents consuming GT polyphenols revealed obvious changes in epithelial gene expression. GT polyphenols are poorly absorbed by digestive tract epithelium. Their metabolism by gut/oral microbial enzymes occurs and can alter absorption and function of these molecules and thus their bioactivity. This might explain the overall lack of consistency in oral epithelium RNA expression changes seen in human subjects who consumed GT. Each human has different gut/oral microbiomes, so they may have different levels of polyphenol-metabolizing bacteria. We speculate the similar gut/oral microbiomes in, for example, mice housed together are responsible for the minimal variance observed in tissue GT responses within a study. The consistency of the tissue response to GT within a rodent study eases the selection of a dose level that affects tumor rates. This leads to the theory that determination of optimal GT doses in a human requires knowledge about the gut/oral microbiome in that human.
\end{abstract}

Keywords: catechin; gene expression; mucosa; oral squamous cell carcinoma

\section{Green Tea Catechins}

Green tea (GT) derived from the leaves of the Camellia sinensis plant is a rich source of the polyphenols known as catechins. A $240 \mathrm{~mL}$ or 8 ounce serving of GT contains, in solution, $300 \mathrm{mg}$ catechins: (-)- epigallocatechin-3-gallate (EGCG), (-)-epigallocatechin, (EGC), (-)-epicatechin-3-gallate (ECG), (-)-epicatechin (EC) [1], and approximately $30 \mathrm{mg}$ of the stimulant caffeine. The catechins are potent antioxidants that can react with and reduce many different reactive oxygen species [2]. While once thought to inhibit carcinogenesis chiefly by inactivation of dietary oxidants, catechins have been shown to have additional properties inside cells that may contribute to the perceived health benefits of drinking GT $[3,4]$. These include interactions with intracellular proteins so to alter: apoptosis, transformed cell proliferation, angiogenesis, DNA repair, and enzymatic detoxification of ROS, etc. [2,4,5]. This review will seek to shed light on why GT or GT catechins are verified oral cancer preventatives in animal models while there is much less evidence for this in humans $[4,6]$. 


\section{GT Inhibition of Rodent Cancer}

Published reviews detail the many rodent studies documenting the ability of GT extract or GT polyphenol consumption to prevent digestive tract tumors [6,7]. Studies of the oral cavity and the esophagus include usage of hamster, rat, and mouse models to show that GT extract or purified polyphenols in drinking water can inhibit the induction of tumors by various carcinogens at both sites [8-13]. Additional studies show efficacy of GT in preventing cancer of the colon and liver, and non-digestive tract sites such as prostate and lung, and that this inhibition can occur whether the GT or GT polyphenols are present during or after carcinogen exposure $[2,14,15]$. There are notable exceptions where no inhibition of tumor formation was observed, even in cases where genetically identical mice were used [6,16-19]. However, at least five published studies alone have shown a cancer preventive effect of GT or GT polyphenols on oral cancer induced by 3 different carcinogens $[8,9,12,20,21]$. GT form or method of application may have differed, and dose may have had some species specificity, but all these studies saw a positive result as shown in Table 1.

Table 1. Extract/polyphenol effects on rodent oral squamous cell carcinoma models.

\begin{tabular}{|c|c|c|c|c|c|c|c|c|}
\hline Species & Catechin Mixture & $\begin{array}{l}\text { Delivery } \\
\text { of GT }\end{array}$ & $\begin{array}{l}\text { Dose of GT } \\
\text { Extract for } \\
\text { Equivalence in } \\
\text { Polyphenols }\end{array}$ & $\begin{array}{c}\text { Duration } \\
\text { of GTE } \\
\text { or GTP } \\
\text { Exposure }\end{array}$ & $\begin{array}{l}\text { Inhibition of } \\
\text { Incidence } \\
6,7\end{array}$ & $\begin{array}{c}\text { Decrease } \\
\text { inTumor } \\
\text { No. }\end{array}$ & $\begin{array}{c}\text { Decrease } \\
\text { in Tumor } \\
\text { Vol. }\end{array}$ & Study \\
\hline $\begin{array}{l}\text { Wistar albino } \\
\text { rats, Male }\end{array}$ & $\begin{array}{c}200 \mathrm{mg} / \mathrm{kg} \text { GT } \\
\text { polyphenol, daily }\end{array}$ & $\begin{array}{l}\text { Drinking } \\
\text { water }\end{array}$ & $600 \mathrm{mg} / \mathrm{kg} \mathrm{GT}$ & 12 weeks & NS & $44 \%$ & $58.6 \%$ & 11 \\
\hline $\begin{array}{l}\text { Syrian Golden } \\
\text { Hamster, Male }{ }^{2}\end{array}$ & $\begin{array}{l}600 \mathrm{mg} / \mathrm{kg} \mathrm{GT} \\
\text { extract daily }\end{array}$ & $\begin{array}{l}\text { Drinking } \\
\text { water }\end{array}$ & $600 \mathrm{mg} / \mathrm{kg} \mathrm{GT}$ & 18 weeks & NS & 35.4 & 57.3 & 19 \\
\hline $\begin{array}{l}\text { Syrian Golden } \\
\text { Hamster, Male }^{3}\end{array}$ & $\begin{array}{c}1500 \mathrm{mg} / \mathrm{kg} \mathrm{GT} \\
\text { extract, daily }\end{array}$ & $\begin{array}{l}\text { Drinking } \\
\text { water }\end{array}$ & 1500 mg/kg GT & 17 weeks & NS & 42.1 & 67.3 & 9 \\
\hline $\begin{array}{l}\mathrm{C} 3 \mathrm{H} / \mathrm{HR} \\
\text { syngeneic } \\
\text { mouse }^{4}\end{array}$ & $\begin{array}{c}25 \mathrm{mg} / \mathrm{kg} \mathrm{GT} \\
\text { polyphenol }\end{array}$ & $\begin{array}{c}\mathrm{IP} \\
\text { injection }\end{array}$ & 75 mg/kg GT & 21 days & NS & ND & 43.6 & 8 \\
\hline $\begin{array}{l}\text { Swiss albino } \\
\text { mice, Male }\end{array}$ & $\begin{array}{l}8 \mathrm{mg} / \mathrm{kg} \mathrm{GT} \\
\text { polyphenol }\end{array}$ & $\begin{array}{c}\text { Oral } \\
\text { gavage }\end{array}$ & $0.002 \mathrm{mg} / \mathrm{kg} \mathrm{GT}$ & 24 weeks & $100 \%$ & ND & ND & 12 \\
\hline
\end{tabular}

${ }^{1}$ GT polyphenol given after 4-Nitroquinoline 1-oxide (4-NQO) oral application completed. ${ }^{2}$ GT extract given for 18 weeks, after 7,12-dimethylbenz[a]anthracene (DMBA) oral application completed. ${ }^{3}$ GT extract given 2 weeks before and then concurrent with 15 weeks DMBA oral application. ${ }^{4}$ ECGC injections after syngeneic mouse tumor cell injections. ${ }^{5}$ ECGC given daily for last 24 weeks of $N$-Nitrosodiethylamine (NDEA) oral application. ${ }^{6}$ Inhibition of incidence of OSCC; or for Swiss albino mice only, moderate to severe dysplasia of tongue. ${ }^{7}$ NS: not significant.

\section{GT Inhibition of Human Cancer}

Human studies have not shown the same consistently high level of efficacy of GT or GT polyphenols in prevention of oral cancer or any other cancers [4,6,7]. Epidemiological studies of esophageal cancers revealed overall little or no association between GT drinking and cancer rates [20,21]. Interestingly, in cohort analyses stratified by sex, protective associations between GT and esophageal cancer were observed for Chinese women [21], and in a case-control study for non-tobacco/non-alcohol users and women users [20]. Studies of oral cancer are similarly variable with limited evidence for GT drinking being a cancer preventive based on epidemiology, though curiously there was a tendency for a benefit in females in a prospective cohort study [22]. An early randomized trial of oral squamous cell carcinoma (OSCC) prevention showed reduction in dysplastic lesions by consuming a GT extract in capsules combined with direct application of $1 \mathrm{~g}$ GT extract to the lesion [23] but a later trial showed no statistically significant benefit of GT in capsules as shown in Table 2 [24]. Notably, GT polyphenols are typically consumed in capsules when tested in recent clinical trials on cancer prevention, unlike human epidemiological studies, which may contribute to results [24-26]. Conflicting findings have also been seen for GT consumption and incidence rates for a number of other cancers, with modestly lower rates of liver and prostate cancer of self-reported tea drinkers based on meta-analysis [27-30]. Furthermore, recent trials designed to examine GT effects on breast cancer risk noted liver toxicity among $5 \%$ of the study subjects taking capsules with the equivalent of 5 cups decaffeinated GT 
daily [26]. Overall, a clear association between GT or GT polyphenol consumption and human cancer prevention has not been verified.

Table 2. Green Tea Polyphenol Clinical Trials.

\begin{tabular}{|c|c|c|c|c|c|}
\hline Catechin Mixture & Delivery & $\begin{array}{l}\text { Dose of GT Extract } \\
\text { for Equivalence in } \\
\text { Polyphenols }\end{array}$ & $\begin{array}{l}\text { Equivalent Level GT as } \\
\text { Beverage (Approx) }\end{array}$ & $\begin{array}{l}\text { Duration of } \\
\text { Exposure }\end{array}$ & Study \\
\hline $3 \mathrm{~g}$ extract/day & Capsule and topical & $55 \mathrm{mg} / \mathrm{kg}$ daily & Unknown & 6 months & [23] \\
\hline $2.6-5.2$ g extract/day & Capsule 3/day & $41-83 \mathrm{mg} / \mathrm{kg}$ daily & $3.5-5$ cups of $240 \mathrm{~mL}$ tea each & 12 weeks & [24] \\
\hline $1.3 \mathrm{~g}$ catechin/day & Capsule 4/day & $60 \mathrm{mg} / \mathrm{kg}$ daily & 4.5 of $240 \mathrm{~mL}$ cups tea & 12 months & [26] \\
\hline
\end{tabular}

\section{Significance of Studying GT Effects In Vivo}

A lack of understanding of GT effects on cells relevant to cancer inhibition has made assessment of the effects of GT on cancer prevention more difficult. Some years ago, it was suggested that GT catechins do not work in vivo chiefly as antioxidants that neutralize oxidizing molecules, but may instead work as regulators of cell function often inside cells [14,31]. While much is known about GT catechin effects on cell lines in vitro [27]), forms of GT catechins in vivo may be quite different than ones seen in vitro, making it difficult to know what in vitro findings are relevant in vivo [32-34]. Plasma and cellular levels of intact catechins are often quite low due to poor uptake by gut epithelium, compared to concentrations used in in vitro studies, as commented on by Yang and Wang [4]. The major tea catechins including EGCG, as predicted by Lipinski's rule of five, due to large size, presence of hydrated shells, and their polarity, are poorly absorbed by cells [4,13,35-37]. In the case of oral epithelium, which is exposed to undiluted GT in tea drinkers, concentrations of catechins are high, hundreds of micrograms per $\mathrm{mL}$, but exposure is transient, so absorption of the unaltered molecules into cells is suboptimal. Thus, to model catechin effects in human tea drinkers, it may be best to focus on in vivo GT studies. On a positive note, there has been some progress in determining GT-induced changes in global gene expression in vivo in rodents, providing information that may inform us on the mechanism of cancer inhibition.

\section{GT and Gene Expression}

Assaying RNA or protein level changes in tissue after consumption of potential bioactive compounds, such as GT, is a rapid method to show if the compound has an effect on the tissue, and may help discern if effects relevant to cancer inhibition occur. There are a limited number of studies published on GT polyphenol effects on epithelial gene expression (or RNA levels) under conditions of carcinogenesis in vivo in rodents but they show clear effects. A lung cancer induction model in mice has been used to identify gene expression changes related to inflammation and regulation of cell proliferation that occur weeks after EGCG exposure in lung adenoma tissue [38]. Analysis of miRNA expression, a major regulator of gene expression in cells, in the same tissue showed changes in miRNAs with EGCG exposure in the same early tumors [39]. These changes parallel the decrease in progression of adenomas to carcinoma due to EGCG in that tumor model and argue that GT exposure is responsible for changes in epithelial gene expression. Multiple studies have shown that with GT exposure or EGCG consumption, tumor-relevant changes in gene expression occur in various rodent tissues [40-42]. There is also extensive evidence of changes in gene expression on the protein level in colons of rodents prone to this cancer that drink or eat GT catechins in their water or food [43-46]. Similar findings have been shown in rodent models of other cancers as reviewed [4].

Published studies of epithelial gene expression changes, induced by catechin or GT extract consumption, in humans, are rare. In a randomized placebo-controlled trial of subjects with oral premalignant changes, immunohistological examination of oral mucosa after 3 months of GT-extract consumption revealed no changes in a range of proteins after exposure. In a subset of those with reduced dysplasia, Cyclin D1 and Vascular Endothelial Growth Factor (VEGF) mucosal levels decreased [24]. 
Brush biopsy offers a noninvasive and validated method optimized for miRNA measurement of oral epithelial cells [47]. After 4 weeks of GT drinking, human tissue exposed to probably the highest concentration of undiluted tea in the body, the tongue epithelium, showed on average no changes in gene expression due to inter-subject variability in levels of miRNA. Only after differential co-expression analysis, which can correct for a lack of a response in some subjects, did GT-induced changes in miRNA expression become evident [48-51]. Non-supervised hierarchical clustering of oral epithelial sample miRNA revealed a group of 5 out of 14 subjects who, after consuming GT, differed most from control subjects who did not consume GT [48]. One might conclude either GT had subtle effects on the tongue epithelium or the effects were subject specific. Another study by Choi et al. studied blood samples from human patients who consumed $300 \mathrm{~mL}$ GT per day. They saw subtle, less than $50 \%$, changes in levels of two redox-linked cytoprotective enzymes [52] and no change in mRNAs were observed. This one study stands in contrast to the many studies that have shown GT-induced changes in gene expression in rodent blood cells and epithelium [38-43,45,46]. Interestingly, human studies of bioactive compounds, such as the catechins and other polyphenols, in general, rarely show changes in levels of specific RNAs. Pokimica et al. have commented on the great variance in gene expression changes with human exposure to GT polyphenols and many other bioactive compounds [53]. Notably, most studies failed to show changes rising to statistical significance in any genes after polyphenol consumption. While technical problems may contribute to low precision in measurement [50], it is also possible different humans are different in their responses to polyphenols like the catechins.

\section{GT Extract and GT Catechin Interactions with Oral and Gut Bacteria}

\subsection{GT Extract and Catechin Effects on Oral and Gut Bacteria}

There is ample evidence that GT catechins are selective antibiotics in vitro, though this effect is concentration-dependent [54-56]. Bacteria diminution is thought to occur via membrane damage, prevention of biofilm formation, enzyme poisoning, etc. [56-58]. Pioneering studies in mammals that focused on several oral bacteria at a time noted changes in oral microbiota with tea or tea extract consumption with consistent reductions in clostridium and increases in bifidobacterium and lactobacillus (Table 3). Two recent human studies broadly examined oral microbiome at genus and species level, after GT or GT extract consumption [48,59]. The first study examined samples from two oral mucosal sites $[59,60]$. The second examined saliva, a mixture of microbes shed from all mucosal and tooth surfaces [61]. After two and four weeks of GT consumption, changes in frequencies of multiple taxa were observed throughout the study populations in both studies. A third microbiome study reported on GT polyphenol effects on gut microbiome but only examined changes on the phylum level [61]. In sum, the reproducible effects of GT consumption on oral and gut genera in human and nonhuman studies suggest GT has direct effects on gut/oral bacteria.

Table 3. Effects on Gut Bacteria.

\begin{tabular}{|c|c|c|c|c|c|}
\hline Catechin Mixture & $\begin{array}{l}\text { Experimental } \\
\text { Subjects }\end{array}$ & $\begin{array}{c}\text { Time of } \\
\text { Exposure }\end{array}$ & $\begin{array}{l}\text { Lower Concentration Gut } \\
\text { Bacteria Post GT or GTE }\end{array}$ & $\begin{array}{l}\text { Higher Concentration Gut } \\
\text { Bacteria Post GT or GTE }\end{array}$ & Study \\
\hline $\begin{array}{c}\text { Green tea extract } \\
0.2 \% \text { in feed }\end{array}$ & Pig & 2 weeks & $\begin{array}{c}\text { Bacteroidacea, } \\
\text { Clostridium perfringens }\end{array}$ & Lactobacillus & [62] \\
\hline $\begin{array}{c}\text { Polyphenon } \mathrm{G}^{1} \\
0.2 \% \text { in feed }\end{array}$ & Chicken & 8 weeks & Enterobactericeace & Lactobacillus & [63] \\
\hline EGCG $0.6 \%$ in feed & Rat & 4 weeks & Clostridium & None & [64] \\
\hline $\begin{array}{l}\text { Green tea extract } \\
1.5 \mathrm{~g} / \text { day in feed }\end{array}$ & Cow & 5 weeks & Clostridium & $\begin{array}{l}\text { Bifidobacterium and } \\
\text { Lactobacillus }\end{array}$ & [65] \\
\hline $\begin{array}{c}\text { Green tea } \\
1000 \mathrm{~mL} / \text { day }\end{array}$ & Human & 10 days & $\begin{array}{c}\text { Clostridium, } \\
\text { Clostridium perfringens }\end{array}$ & Bifidobacterium & {$[66]$} \\
\hline $\begin{array}{c}\text { Sunphenon } \\
\text { (green tea catechin) } \\
1.2 \mathrm{~g} / \text { day }\end{array}$ & Human & 4 weeks & None & Bifidobacterium & {$[67]$} \\
\hline
\end{tabular}

${ }^{1}$ Reduced caffeine. 


\subsection{Gut and Oral Bacteria May Metabolize GT Polyphenols}

There is much evidence that gut bacteria metabolize dietary polyphenols. This can, in theory, transform them into more bioavailable forms and stimulate uptake into digestive tract epithelium [68-71]. Years ago, it was shown that GT catechins can be metabolized by intestinal bacterial enzymes. A number of groups have characterized these reactions chiefly by two approaches: (1) examination of products present in blood, urine and feces post-catechin consumption; and (2) incubation of catechin of interest, chiefly EGCG with rat gut contents in vitro. Of the 4 major catechins in GT, EGCG, EGC, ECG, and EG, peak blood levels, in humans and rodents, reach about $1.0 \mu \mathrm{M}$ for each due to low absorption by digestive tract epithelium [4,32,72]. Metabolism by gut microbes of ingested EGCG, EGC, and EC creates 5-(3'4'-dihydroxyphenyl)- $\gamma$-valerolactone, 3-(3-hydroxyphenyl) propionic acid and other compounds [73-77]. Braune and Blaut have described the inroads that have been made in identifying the colonic bacteria that perform the hydrolysis of ester bonds, reductive cleavage of the $C$ ring and further reactions of GT catechin catabolism (Figure 1) though little is known about the enzymes responsible [78]. Recent work correlating specific taxa with levels of the first catechin metabolites has hinted at a number of human gut bacteria as candidates to contribute to this process including R. bromii and Eggerthella, the latter already known to be involved [79]. Studies of humans are beginning to reveal inter-individual variability in GT catechin metabolism by digestive tract bacteria relevant to health [80,81]. In a small study, human subjects who consumed high levels of green tea polyphenol mixture, without caffeine, over 8 weeks, had differently hydroxylated phenyl- $\gamma$-valerolactones and 3-(3'-hydroxyphenyl)propionic acid in their urine suggesting different levels of enzymes performing the C-ring cleavage of GT catechins, the dehydroxylation of phenyl- $\gamma$-valerolactones and the conversion of t phenyl- $\gamma$-valerolactones into 3-(phenyl)propionic acids, [74,77,82,83]. Some GT metabolites are more readily taken up by cells than the parent compounds and still retain biological activities relevant to carcinogenesis at least in vitro [84,85]. More extensive metabolism of GT catechins results in biologically inactive phenols that are excreted. It has been shown that removal of gut bacteria by extended antibiotic exposure results in increased levels of intact GT catechins in feces and serum showing the importance of the microbiota in GT metabolism [86]. Unfortunately, the study did not report on levels of absorbed GT catechin metabolites. The mouth is also a rich site of microbes, and there is some evidence that these microbes can metabolize tea catechins, to more readily absorbable valerolactones, though the process is not well described [87]. Importantly digestive tract bacteria, best documented for the colon, have the ability to metabolize catechins, supplementing the body's own metabolism of these molecules [32]. Whether the oral epithelium absorbs the bulk of GT catechins and their metabolites directly from the tea/salvia or via blood is not known.

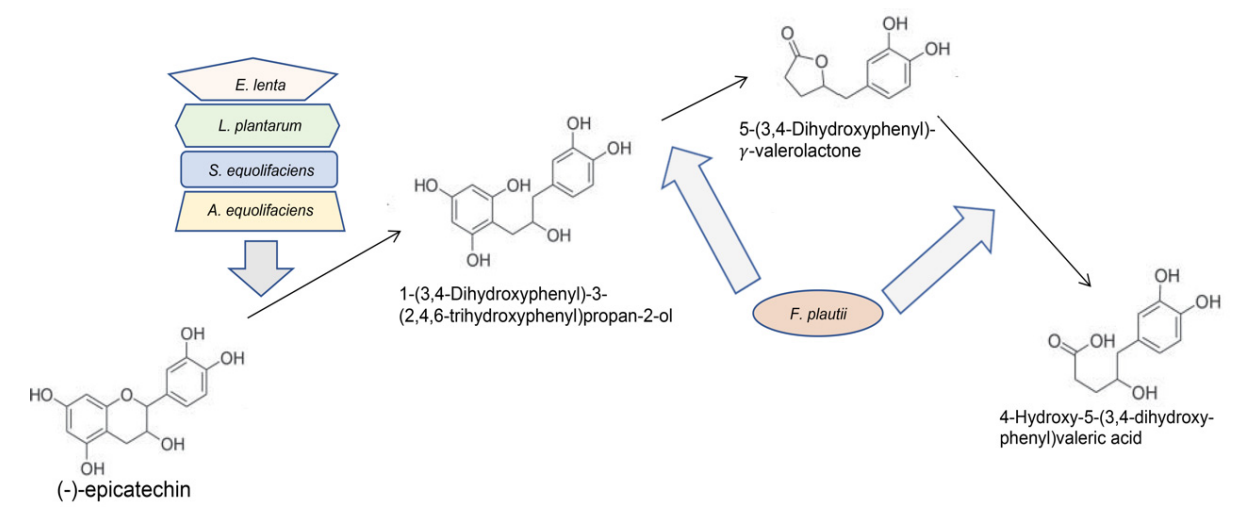

Figure 1. Initial products of metabolism of green tea (GT) (-)-epicatechin (EC). Four gut bacteria have enzymes to execute the first $\mathrm{C}$ ring cleavage step, while $\mathrm{F}$ plautii has been shown to be capable of further metabolism.

One may speculate that gut/oral microbiota may play a role in the differences in rodent versus human responses to GT. In animal studies of GT, GT catechins or other chemicals have been shown to 
induce physiological changes, gene expression changes, and prevent and slow progression of a variety of cancers in the animals, which are housed together. Animals in the same cage show high levels of similarity in gut microbiome [88-90]. Rodents in a single facility are known to show many more similarities in microbiota than animals in a different facility, due to shared diet and other unknown factors [90-92]. In a study with all mice in a single room, the way almost all rodent studies of GT are done, gut microbiota are more similar than not, especially in cases where the animals are also homozygous, as genetic differences can contribute to mucosal microbiota identity [93]. A separate study done at a second facility would likely have different gut/oral microbiota [90-93]. Since gut and likely oral microbiota have the ability to modify GT catechins, and change bioavailability of tea catechins, one would expect that responses to poorly bioavailable GT compounds would be uniform within a cohort with similar oral microbiota and gut microbiota [68-71]. This would explain the ease in detecting changes in gene expression brought about by GT exposure in rodent studies, as intraclass variation would be minimal within the study as long as the mice were housed together. A second issue is that the uniformity of GT effects within a study would make it easier to optimize dose to see maximal phenotypic changes and to avoid toxicity. The optimal GT or GT extract dose at a second study site would likely be different but would, for the same reason, be easy to optimize. For example, too high a dose would be toxic to all rodents, not just a few, and would be harder to miss. Usage of an optimal GT dose would make it more likely that GT would be active across all animals and have an effect on tumor rates. In some studies where no optimization of GT dosage for the individual cohort was done, one would predict no effect on tumor rates might be seen and there are a small number of published rodent studies where GT did not affect tumor rates [4,15-18]. Consistent with this model is that the dosage of GT polyphenols chosen to inhibit OSCC in mice, and not be toxic, is variable (Table 1), as seen with other cancers $[8,12,94,95]$.

\section{Model for How Variable Gut and Oral Microbiota may Affect GT Studies on Humans}

People who are non-cohabitating show a great variety of oral and gut microbiota which is reduced in those who live together $[96,97]$. Diet $[98,99]$, gut/oral health $[100,101]$, and drugs $[102,103]$ may further influence gut and oral microbiota. Clinical studies on GT-based prevention do not normally account for variation of aerodigestive tract microbiota or the foods, beverages, and medications ingested. As a result, one would predict that responses to supplemental polyphenol and GT itself would be variable. Whether one is assaying changes in cell function [104] or histological changes in cancer-prone sites [24], rarely is a consistent net positive result seen across a sample of human subjects. This may be due to the differences in GT metabolizing digestive tract microbes that we suggest are crucial for catechin uptake, turnover, and/or function [35,70,105]. As a result, levels of GT extract that may be appropriate for most individual humans are much too high, for example, in subjects with gut/oral microbes most efficient at converting GT polyphenols to metabolites that are bioactive. Conversely, a study on a rodent cohort consuming GT polyphenols, with bioactivity dependent on digestive tract microbiota which vary little, would reveal consistent changes in gene expression. This would ease GT dosage optimization in a rodent study and make it fairly likely that changes in cancer incidence would be observed (Figure 2). In clinical trials, using humans with variable gut/oral microbiota, that would not be the case [106]. For example, humans with high levels of gut/oral bacteria that metabolize GT polyphenol to functional, readily absorbed metabolites might show toxicity, while those with gut/oral bacteria that lack this metabolic activity may show no effect [26]. With heterogeneous populations, a dosage would be chosen tolerable to all but the most sensitive subjects. It would vary little between studies and be on-average ineffective and that is what has been observed (Table 2). This is in contrast to rodent studies where levels of catechins given to experimental subjects vary between studies (Table 1). One possible solution is to artificially convert GT polyphenols to forms that are more readily absorbed by cells $[35,107]$. Another would be to characterize subject specific GT toxicity, possibly by measuring each subject's gut/oral microbiota and its ability to activate and inactivate GT catechins, prior to entry in the trial, or more directly measuring GT metabolites after the study starts. 


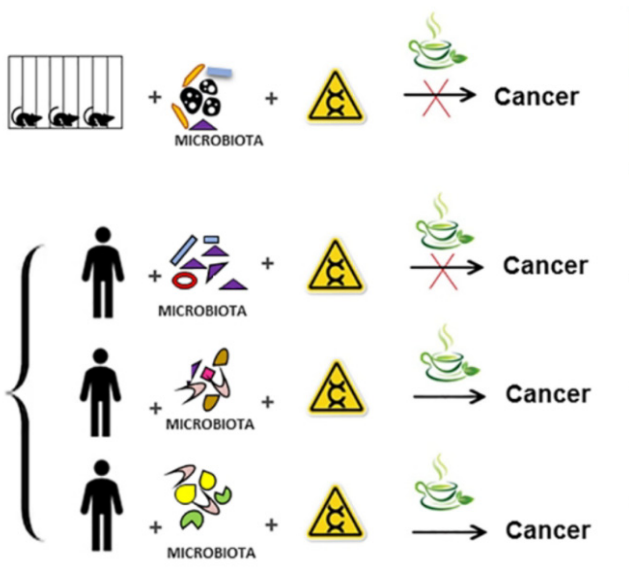

Similar gut/oral microbiota in cohoused subjects. GT response uniform, easy to optimize. See clear cancer inhibition in most but not all studies.

Figure 2. Model of shared oral/gut microbiota on ability of GT and GT polyphenols to prevent cancer.

$\triangle$ represents a bacterium that is efficient at converting GT polyphenols to bioactive forms readily absorbed by digestive tract epithelial cells. The human with high levels of this bacterium would readily process GT catechins to active, absorbed forms, and show a response. The other two humans who lack this bacterium would not.

This comparison of rodent and human studies points out a role for digestive tract microbiota in the disparate results in inhibition of OSCC and other cancers in rodents versus humans. It is not evident what is more important in the oral cancer process, how GT changes the oral microbiome, or direct effects of GT on the oral mucosa. Other differences in human and rodent studies, such as methods of ingestion, liquid or capsule, and sex of the subjects, may contribute to differences in oral cancer inhibition in human versus rodents.

Author Contributions: Conceptualization, G.R.A., C.T., J.L.S., writing-original draft preparation, review and editing, G.R.A., C.T., J.L.S. and K.C.D. All authors have read and agreed to the published version of the manuscript.

Funding: This work was funded by grants from the National Cancer Institute, grant numbers R03CA178843 and R03CA150076. The APC was not funded externally.

Acknowledgments: We thank Martha Carlson for help in manuscript preparation.

Conflicts of Interest: The authors declare no conflict of interest.

\section{References}

1. Balentine, D.A.; Wiseman, S.A.; Bouwens, L.C. The chemistry of tea flavonoids. Crit. Rev. Food Sci. Nutr. 1997, 37, 693-704. [CrossRef] [PubMed]

2. Chen, L.; Mo, H.; Zhao, L.; Gao, W.; Wang, S.; Cromie, M.M.; Lu, C.; Wang, J.S.; Shen, C.L. Therapeutic properties of green tea against environmental insults. J. Nutr. Biochem. 2017, 40, 1-13. [CrossRef] [PubMed]

3. Halliwell, B.; Rafter, J.; Jenner, A. Health promotion by flavonoids, tocopherols, tocotrienols, and other phenols: Direct or indirect effects? Antioxidant or not? Am. J. Clin. Nutr. 2005, 81, 268S-276S. [CrossRef] [PubMed]

4. Yang, C.S.; Wang, H. Cancer Preventive Activities of Tea Catechins. Molecules 2016, 21, 1679. [CrossRef]

5. Tao, L.; Park, J.Y.; Lambert, J.D. Differential prooxidative effects of the green tea polyphenol, (-)-epigallocatechin-3-gallate, in normal and oral cancer cells are related to differences in sirtuin 3 signaling. Mol. Nutr. Food Res. 2015, 59, 203-211. [CrossRef]

6. Yang, C.S.; Wang, X.; Lu, G.; Picinich, S.C. Cancer prevention by tea: Animal studies, molecular mechanisms and human relevance. Nat. Rev. Cancer 2009, 9, 429-439. [CrossRef]

7. Wang, L.X.; Shi, Y.L.; Zhang, L.J.; Wang, K.R.; Xiang, L.P.; Cai, Z.Y.; Lu, J.L.; Ye, J.H.; Liang, Y.R.; Zheng, X.Q. Inhibitory Effects of (-)-Epigallocatechin-3-gallate on Esophageal Cancer. Molecules 2019, 24, 954. [CrossRef]

8. Koh, Y.W.; Choi, E.C.; Kang, S.U.; Hwang, H.S.; Lee, M.H.; Pyun, J.; Park, R.; Lee, Y.; Kim, C.H. Green tea (-)-epigallocatechin-3-gallate inhibits HGF-induced progression in oral cavity cancer through suppression of HGF/c-Met. J. Nutr. Biochem. 2011, 22, 1074-1083. [CrossRef] 
9. Li, N.; Chen, X.; Liao, J.; Yang, G.; Wang, S.; Josephson, Y.; Han, C.; Chen, J.; Huang, M.T.; Yang, C.S. Inhibition of 7,12-dimethylbenz[a]anthracene (DMBA)-induced oral carcinogenesis in hamsters by tea and curcumin. Carcinogenesis 2002, 23, 1307-1313. [CrossRef]

10. Morse, M.A.; Kresty, L.A.; Steele, V.E.; Kelloff, G.J.; Boone, C.W.; Balentine, D.A.; Harbowy, M.E.; Stoner, G.D. Effects of theaflavins on $N$-nitrosomethylbenzylamine-induced esophageal tumorigenesis. Nutr. Cancer 1997, 29, 7-12. [CrossRef]

11. Srinivasan, P.; Suchalatha, S.; Babu, P.V.; Devi, R.S.; Narayan, S.; Sabitha, K.E.; Devi, C.S.S. Chemopreventive and therapeutic modulation of green tea polyphenols on drug metabolizing enzymes in 4-Nitroquinoline 1-oxide induced oral cancer. Chem. Biol. Interact. 2008, 172, 224-234. [CrossRef] [PubMed]

12. Sur, S.; Pal, D.; Roy, R.; Barua, A.; Roy, A.; Saha, P.; Panda, C.K. Tea polyphenols EGCG and TF restrict tongue and liver carcinogenesis simultaneously induced by $N$-nitrosodiethylamine in mice. Toxicol. Appl. Pharmacol. 2016, 300, 34-46. [CrossRef] [PubMed]

13. Yang, C.S.; Chen, J.X.; Wang, H.; Lim, J. Lessons learned from cancer prevention studies with nutrients and non-nutritive dietary constituents. Mol. Nutr. Food Res. 2016, 60, 1239-1250. [CrossRef] [PubMed]

14. Yang, C.S.; Wang, H. Mechanistic issues concerning cancer prevention by tea catechins. Mol. Nutr. Food Res. 2011, 55, 819-831. [CrossRef]

15. Fiala, E.S.; Sohn, O.S.; Wang, C.X.; Seibert, E.; Tsurutani, J.; Dennis, P.A.; El-Bayoumy, K.; Sodum, R.S.; Desai, D.; Reinhardt, J.; et al. Induction of preneoplastic lung lesions in guinea pigs by cigarette smoke inhalation and their exacerbation by high dietary levels of vitamins $C$ and E. Carcinogenesis 2005, 26, 605-612. [CrossRef]

16. Hu, Y.; Le Leu, R.K.; Christophersen, C.T.; Somashekar, R.; Conlon, M.A.; Meng, X.Q.; Winter, J.M.; Woodman, R.J.; McKinnon, R.; Young, G.P. Manipulation of the gut microbiota using resistant starch is associated with protection against colitis-associated colorectal cancer in rats. Carcinogenesis 2016, 37, 366-375. [CrossRef]

17. Witschi, H. Successful and not so successful chemoprevention of tobacco smoke-induced lung tumors. Exp. Lung Res. 2000, 26, 743-755. [CrossRef]

18. Witschi, H.; Espiritu, I.; Yu, M.; Willits, N.H. The effects of phenethyl isothiocyanate, N-acetylcysteine and green tea on tobacco smoke-induced lung tumors in strain A/J mice. Carcinogenesis 1998, 19, 1789-1794. [CrossRef]

19. Li, N.; Han, C.; Chen, J. Tea preparations protect against DMBA-induced oral carcinogenesis in hamsters. Nutr. Cancer 1999, 35, 73-79. [CrossRef]

20. Gao, Y.T.; McLaughlin, J.K.; Blot, W.J.; Ji, B.T.; Dai, Q.; Fraumeni, J.F., Jr. Reduced risk of esophageal cancer associated with green tea consumption. J. Natl. Cancer Inst. 1994, 86, 855-858. [CrossRef]

21. Zheng, P.; Zheng, H.M.; Deng, X.M.; Zhang, Y.D. Green tea consumption and risk of esophageal cancer: A meta-analysis of epidemiologic studies. BMC Gastroenterol. 2012, 12, 165. [CrossRef] [PubMed]

22. Ide, R.; Fujino, Y.; Hoshiyama, Y.; Mizoue, T.; Kubo, T.; Pham, T.M.; Shirane, K.; Tokui, N.; Sakata, K.; Tamakoshi, A.; et al. A prospective study of green tea consumption and oral cancer incidence in Japan. Ann. Epidemiol. 2007, 17, 821-826. [CrossRef] [PubMed]

23. Li, N.; Sun, Z.; Han, C.; Chen, J. The chemopreventive effects of tea on human oral precancerous mucosa lesions. Proc. Soc. Exp. Biol. Med. 1999, 220, 218-224. [PubMed]

24. Tsao, A.S.; Liu, D.; Martin, J.; Tang, X.M.; Lee, J.J.; El-Naggar, A.K.; Wistuba, I.; Culotta, K.S.; Mao, L.; Gillenwater, A.; et al. Phase II randomized, placebo-controlled trial of green tea extract in patients with high-risk oral premalignant lesions. Cancer Prev. Res. 2009, 2, 931-941. [CrossRef] [PubMed]

25. Tang, G.Y.; Meng, X.; Gan, R.Y.; Zhao, C.N.; Liu, Q.; Feng, Y.B.; Li, S.; Wei, X.L.; Atanasov, A.G.; Corke, H.; et al. Health Functions and Related Molecular Mechanisms of Tea Components: An Update Review. Int. J. Mol. Sci. 2019, 20, 6196. [CrossRef]

26. Yu, Z.; Samavat, H.; Dostal, A.M.; Wang, R.; Torkelson, C.J.; Yang, C.S.; Butler, L.M.; Kensler, T.W.; Wu, A.H.; Kurzer, M.S.; et al. Effect of Green Tea Supplements on Liver Enzyme Elevation: Results from a Randomized Intervention Study in the United States. Cancer Prev. Res. 2017, 10, 571-579. [CrossRef]

27. Almatroodi, S.A.; Almatroudi, A.; Khan, A.A.; Alhumaydhi, F.A.; Alsahli, M.A.; Rahmani, A.H. Potential Therapeutic Targets of Epigallocatechin Gallate (EGCG), the Most Abundant Catechin in Green Tea, and Its Role in the Therapy of Various Types of Cancer. Molecules 2020, 25, 3146. [CrossRef]

28. Boehm, K.; Borrelli, F.; Ernst, E.; Habacher, G.; Hung, S.K.; Milazzo, S.; Horneber, M. Green tea (Camellia sinensis) for the prevention of cancer. Cochrane Database Syst. Rev. 2009, CD005004. [CrossRef] 
29. Jacob, S.A.; Khan, T.M.; Lee, L.H. The Effect of Green Tea Consumption on Prostate Cancer Risk and Progression: A Systematic Review. Nutr. Cancer 2017, 69, 353-364. [CrossRef]

30. Ni, Y.; Li, J.; Panagiotou, G. A Molecular-Level Landscape of Diet-Gut Microbiome Interactions: Toward Dietary Interventions Targeting Bacterial Genes. MBio 2015, 6. [CrossRef]

31. Halliwell, B. Are polyphenols antioxidants or pro-oxidants? What do we learn from cell culture and in vivo studies? Arch. Biochem. Biophys. 2008, 476, 107-112. [CrossRef] [PubMed]

32. Del Rio, D.; Calani, L.; Cordero, C.; Salvatore, S.; Pellegrini, N.; Brighenti, F. Bioavailability and catabolism of green tea flavan-3-ols in humans. Nutrition 2010, 26, 1110-1116. [CrossRef]

33. Halliwell, B. Cell culture, oxidative stress, and antioxidants: Avoiding pitfalls. Biomed. J. 2014, 37, 99-105. [CrossRef] [PubMed]

34. Takagaki, A.; Nanjo, F. Metabolism of (-)-epigallocatechin gallate by rat intestinal flora. J. Agric. Food Chem. 2010, 58, 1313-1321. [CrossRef]

35. Cai, Z.Y.; Li, X.M.; Liang, J.P.; Xiang, L.P.; Wang, K.R.; Shi, Y.L.; Yang, R.; Shi, M.; Ye, J.H.; Lu, J.L.; et al. Bioavailability of Tea Catechins and Its Improvement. Molecules 2018, 23, 2346. [CrossRef]

36. Liang, W.; Binns, C.W.; Jian, L.; Lee, A.H. Does the consumption of green tea reduce the risk of lung cancer among smokers? Evid. Based Complement. Alternat. Med. 2007, 4, 17-22. [CrossRef] [PubMed]

37. Lipinski, C.A.; Lombardo, F.; Dominy, B.W.; Feeney, P.J. Experimental and computational approaches to estimate solubility and permeability in drug discovery and development settings. Adv. Drug Deliv. Rev. 2001, 46, 3-26. [CrossRef]

38. Lu, Y.; Yao, R.; Yan, Y.; Wang, Y.; Hara, Y.; Lubet, R.A.; You, M. A gene expression signature that can predict green tea exposure and chemopreventive efficacy of lung cancer in mice. Cancer Res. 2006, 66, 1956-1963. [CrossRef]

39. Zhou, H.; Chen, J.X.; Yang, C.S.; Yang, M.Q.; Deng, Y.; Wang, H. Gene regulation mediated by microRNAs in response to green tea polyphenol EGCG in mouse lung cancer. BMC Genom. 2014, 15. [CrossRef]

40. Newsome, B.J.; Petriello, M.C.; Han, S.G.; Murphy, M.O.; Eske, K.E.; Sunkara, M.; Morris, A.J.; Hennig, B. Green tea diet decreases PCB 126-induced oxidative stress in mice by up-regulating antioxidant enzymes. J. Nutr. Biochem. 2014, 25, 126-135. [CrossRef]

41. Siddiqui, I.A.; Asim, M.; Hafeez, B.B.; Adhami, V.M.; Tarapore, R.S.; Mukhtar, H. Green tea polyphenol EGCG blunts androgen receptor function in prostate cancer. FASEB J. 2011, 25, 1198-1207. [CrossRef] [PubMed]

42. Toden, S.; Tran, H.M.; Tovar-Camargo, O.A.; Okugawa, Y.; Goel, A. Epigallocatechin-3-gallate targets cancer stem-like cells and enhances 5-fluorouracil chemosensitivity in colorectal cancer. Oncotarget 2016, 7, 16158-16171. [CrossRef]

43. Hao, X.; Sun, Y.; Yang, C.S.; Bose, M.; Lambert, J.D.; Ju, J.; Lu, G.; Lee, M.J.; Park, S.; Husain, A.; et al. Inhibition of intestinal tumorigenesis in $\mathrm{Apc}(\mathrm{min} /+)$ mice by green tea polyphenols (polyphenon $\mathrm{E})$ and individual catechins. Nutr. Cancer 2007, 59, 62-69. [CrossRef]

44. Ko, S.Y.; Chang, K.W.; Lin, S.C.; Hsu, H.C.; Liu, T.Y. The repressive effect of green tea ingredients on amyloid precursor protein (APP) expression in oral carcinoma cells in vitro and in vivo. Cancer Lett. 2007, 245, 81-89. [CrossRef]

45. Shimizu, M.; Shirakami, Y.; Sakai, H.; Adachi, S.; Hata, K.; Hirose, Y.; Tsurumi, H.; Tanaka, T.; Moriwaki, H. (-)-Epigallocatechin gallate suppresses azoxymethane-induced colonic premalignant lesions in male C57BL/KsJ-db/db mice. Cancer Prev. Res. 2008, 1, 298-304. [CrossRef] [PubMed]

46. Xiao, H.; Hao, X.; Simi, B.; Ju, J.; Jiang, H.; Reddy, B.S.; Yang, C.S. Green tea polyphenols inhibit colorectal aberrant crypt foci (ACF) formation and prevent oncogenic changes in dysplastic ACF in azoxymethane-treated F344 rats. Carcinogenesis 2008, 29, 113-119. [CrossRef] [PubMed]

47. Adami, G.R.; Tang, J.L.; Markiewicz, M.R. Improving accuracy of RNA-based diagnosis and prognosis of oral cancer by using noninvasive methods. Oral Oncol. 2017, 69, 62-67. [CrossRef]

48. Adami, G.R.; Tangney, C.C.; Tang, J.L.; Zhou, Y.; Ghaffari, S.; Naqib, A.; Sinha, S.; Green, S.J.; Schwartz, J.L. Effects of green tea on miRNA and microbiome of oral epithelium. Sci. Rep. 2018, 8, 5873. [CrossRef]

49. de la Fuente, A. From 'differential expression' to 'differential networking' - Identification of dysfunctional regulatory networks in diseases. Trends Genet. 2010, 26, 326-333. [CrossRef]

50. McShane, L.M.; Radmacher, M.D.; Freidlin, B.; Yu, R.; Li, M.C.; Simon, R. Methods for assessing reproducibility of clustering patterns observed in analyses of microarray data. Bioinformatics 2002, 18, 1462-1469. [CrossRef] 
51. Voigt, A.; Nowick, K.; Almaas, E. A composite network of conserved and tissue specific gene interactions reveals possible genetic interactions in glioma. PLoS Comput. Biol. 2017, 13, e1005739. [CrossRef] [PubMed]

52. Choi, S.W.; Yeung, V.T.; Collins, A.R.; Benzie, I.F. Redox-linked effects of green tea on DNA damage and repair, and influence of microsatellite polymorphism in HMOX-1: Results of a human intervention trial. Mutagenesis 2015, 30, 129-137. [CrossRef]

53. Pokimica, B.; Garcia-Conesa, M.T. Critical Evaluation of Gene Expression Changes in Human Tissues in Response to Supplementation with Dietary Bioactive Compounds: Moving towards Better-Quality Studies. Nutrients 2018, 10, 807. [CrossRef] [PubMed]

54. Araghizadeh, A.; Kohanteb, J.; Fani, M.M. Inhibitory activity of green tea (Camellia sinensis) extract on some clinically isolated cariogenic and periodontopathic bacteria. Med. Princ. Pract. 2013, 22, 368-372. [CrossRef] [PubMed]

55. Lee, H.C.; Jenner, A.M.; Low, C.S.; Lee, Y.K. Effect of tea phenolics and their aromatic fecal bacterial metabolites on intestinal microbiota. Res. Microbiol. 2006, 157, 876-884. [CrossRef] [PubMed]

56. Steinmann, J.; Buer, J.; Pietschmann, T.; Steinmann, E. Anti-infective properties of epigallocatechin-3-gallate (EGCG), a component of green tea. Br. J. Pharmacol. 2013, 168, 1059-1073. [CrossRef]

57. Reygaert, W.C. Green Tea Catechins: Their Use in Treating and Preventing Infectious Diseases. Biomed. Res. Int. 2018, 2018, 9105261. [CrossRef]

58. Stenvang, M.; Dueholm, M.S.; Vad, B.S.; Seviour, T.; Zeng, G.; Geifman-Shochat, S.; Sondergaard, M.T.; Christiansen, G.; Meyer, R.L.; Kjelleberg, S.; et al. Epigallocatechin Gallate Remodels Overexpressed Functional Amyloids in Pseudomonas aeruginosa and Increases Biofilm Susceptibility to Antibiotic Treatment. J. Biol. Chem. 2016, 291, 26540-26553. [CrossRef]

59. Yuan, X.; Long, Y.; Ji, Z.; Gao, J.; Fu, T.; Yan, M.; Zhang, L.; Su, H.; Zhang, W.; Wen, X.; et al. Green Tea Liquid Consumption Alters the Human Intestinal and Oral Microbiome. Mol. Nutr. Food Res. 2018, 62, 1800178. [CrossRef]

60. Dawes, C. Estimates, from salivary analyses, of the turnover time of the oral mucosal epithelium in humans and the number of bacteria in an edentulous mouth. Arch. Oral Biol. 2003, 48, 329-336. [CrossRef]

61. Janssens, P.L.; Penders, J.; Hursel, R.; Budding, A.E.; Savelkoul, P.H.; Westerterp-Plantenga, M.S. Long-Term Green Tea Supplementation Does Not Change the Human Gut Microbiota. PLoS ONE 2016, 11, e0153134. [CrossRef]

62. Hara, H.; Orita, N.; Hatano, S.; Ichikawa, H.; Hara, Y.; Matsumoto, N.; Kimura, Y.; Terada, A.; Mitsuoka, T. Effect of tea polyphenols on fecal flora and fecal metabolic products of pigs. J. Vet. Med. Sci. 1995, 57, 45-49. [CrossRef] [PubMed]

63. Hara, Y. Influence of tea catechins on the digestive tract. J. Cell. Biochem. 1997, 27, 52-58. [CrossRef]

64. Unno, T.; Sakuma, M.; Mitsuhashi, S. Effect of dietary supplementation of (-)-epigallocatechin gallate on gut microbiota and biomarkers of colonic fermentation in rats. J. Nutr. Sci. Vitaminol. 2014, 60, 213-219. [CrossRef] [PubMed]

65. Ishihara, N.; Chu, D.-C.; Akachi, S.; Juneja, K. Improvement of intestinal microflora balance and prevention of digestive and respiratory organ diseases in calves by green tea extracts. Livest. Prod. Sci. 2001, 68, 217-229. [CrossRef]

66. Jin, J.S.; Touyama, M.; Hisada, T.; Benno, Y. Effects of green tea consumption on human fecal microbiota with special reference to Bifidobacterium species. Microbiol. Immunol. 2012, 56, 729-739. [CrossRef] [PubMed]

67. Okubo, T.; Ishihara, N.; Oura, A.; Serit, M.; Kim, M.; Yamamoto, T.; Mitsuoka, T. In Vivo Effects of Tea Polyphenol Intake on Human Intestinal Microflora and Metabolism. Biosci. Biotechnol. Biochem. 1992, 56, 588-591. [CrossRef]

68. Cassidy, A.; Minihane, A.M. The role of metabolism (and the microbiome) in defining the clinical efficacy of dietary flavonoids. Am. J. Clin. Nutr. 2017, 105, 10-22. [CrossRef]

69. Duenas, M.; Munoz-Gonzalez, I.; Cueva, C.; Jimenez-Giron, A.; Sanchez-Patan, F.; Santos-Buelga, C.; Moreno-Arribas, M.V.; Bartolome, B. A survey of modulation of gut microbiota by dietary polyphenols. Biomed. Res. Int. 2015, 2015, 850902. [CrossRef]

70. Ozdal, T.; Sela, D.A.; Xiao, J.; Boyacioglu, D.; Chen, F.; Capanoglu, E. The Reciprocal Interactions between Polyphenols and Gut Microbiota and Effects on Bioaccessibility. Nutrients 2016, 8, 78. [CrossRef]

71. Williamson, G.; Clifford, M.N. Role of the small intestine, colon and microbiota in determining the metabolic fate of polyphenols. Biochem. Pharmacol. 2017, 139, 24-39. [CrossRef] [PubMed] 
72. Yang, C.S.; Chen, L.; Lee, M.J.; Balentine, D.; Kuo, M.C.; Schantz, S.P. Blood and urine levels of tea catechins after ingestion of different amounts of green tea by human volunteers. Cancer Epidemiol. Biomark. Prev. 1998, 7, 351-354.

73. Jin, J.S.; Hattori, M. Isolation and characterization of a human intestinal bacterium Eggerthella sp. CAT-1 capable of cleaving the C-ring of (+)-catechin and (-)-epicatechin, followed by p-dehydroxylation of the B-ring. Biol. Pharm. Bull. 2012, 35, 2252-2256. [CrossRef] [PubMed]

74. Kutschera, M.; Engst, W.; Blaut, M.; Braune, A. Isolation of catechin-converting human intestinal bacteria. J. Appl. Microbiol. 2011, 111, 165-175. [CrossRef]

75. Sanchez-Patan, F.; Tabasco, R.; Monagas, M.; Requena, T.; Pelaez, C.; Moreno-Arribas, M.V.; Bartolome, B. Capability of Lactobacillus plantarum IFPL935 to catabolize flavan-3-ol compounds and complex phenolic extracts. J. Agric. Food Chem. 2012, 60, 7142-7151. [CrossRef] [PubMed]

76. Takagaki, A.; Nanjo, F. Effects of Metabolites Produced from (-)-Epigallocatechin Gallate by Rat Intestinal Bacteria on Angiotensin I-Converting Enzyme Activity and Blood Pressure in Spontaneously Hypertensive Rats. J. Agric. Food Chem. 2015, 63, 8262-8266. [CrossRef]

77. Takagaki, A.; Nanjo, F. Bioconversion of (-)-epicatechin, (+)-epicatechin, (-)-catechin, and (+)-catechin by (-)-epigallocatechin-metabolizing bacteria. Biol. Pharm. Bull. 2015, 38, 789-794. [CrossRef]

78. Braune, A.; Blaut, M. Bacterial species involved in the conversion of dietary flavonoids in the human gut. Gut Microbes 2016, 7, 216-234. [CrossRef]

79. Liu, Z.; de Bruijn, W.J.C.; Bruins, M.E.; Vincken, J.P. Reciprocal Interactions between Epigallocatechin-3-gallate (EGCG) and Human Gut Microbiota In Vitro. J. Agric. Food Chem. 2020, 68, 9804-9815. [CrossRef]

80. Espín, J.C.; González-Sarrías, A.; Tomás-Barberán, F.A. The gut microbiota: A key factor in the therapeutic effects of (poly)phenols. Biochem. Pharmacol. 2017, 139, 82-93. [CrossRef]

81. FA 1403-POSITIVe: Interindividual Variation in Response to Consumption of Plant Food Bioactives and Determinants Involved. Available online: https://www6.inrae.fr/cost-positive/Dissemination/PublicationsOutcomes (accessed on 5 October 2020).

82. Gonthier, M.P.; Donovan, J.L.; Texier, O.; Felgines, C.; Remesy, C.; Scalbert, A. Metabolism of dietary procyanidins in rats. Free Radic. Biol. Med. 2003, 35, 837-844. [CrossRef]

83. Mena, P.; Ludwig, I.A.; Tomatis, V.B.; Acharjee, A.; Calani, L.; Rosi, A.; Brighenti, F.; Ray, S.; Griffin, J.L.; Bluck, L.J.; et al. Inter-individual variability in the production of flavan-3-ol colonic metabolites: Preliminary elucidation of urinary metabotypes. Eur. J. Nutr. 2019, 58, 1529-1543. [CrossRef] [PubMed]

84. Marquez Campos, E.; Stehle, P.; Simon, M.C. Microbial Metabolites of Flavan-3-Ols and Their Biological Activity. Nutrients 2019, 11, 2260. [CrossRef] [PubMed]

85. Mena, P.; Bresciani, L.; Brindani, N.; Ludwig, I.A.; Pereira-Caro, G.; Angelino, D.; Llorach, R.; Calani, L.; Brighenti, F.; Clifford, M.N.; et al. Phenyl-gamma-valerolactones and phenylvaleric acids, the main colonic metabolites of flavan-3-ols: Synthesis, analysis, bioavailability, and bioactivity. Nat. Prod. Rep. 2019, 36, 714-752. [CrossRef]

86. Liu, A.B.; Tao, S.; Lee, M.J.; Hu, Q.; Meng, X.; Lin, Y.; Yang, C.S. Effects of gut microbiota and time of treatment on tissue levels of green tea polyphenols in mice. Biofactors 2018, 44, 348-360. [CrossRef] [PubMed]

87. Yang, C.S.; Lee, M.J.; Chen, L. Human salivary tea catechin levels and catechin esterase activities: Implication in human cancer prevention studies. Cancer Epidemiol. Biomark. Prev. 1999, 8, 83-89.

88. Alexander, A.D.; Orcutt, R.P.; Henry, J.C.; Baker, J., Jr.; Bissahoyo, A.C.; Threadgill, D.W. Quantitative PCR assays for mouse enteric flora reveal strain-dependent differences in composition that are influenced by the microenvironment. Mamm. Genome 2006, 17, 1093-1104. [CrossRef]

89. Hildebrand, F.; Nguyen, T.L.; Brinkman, B.; Yunta, R.G.; Cauwe, B.; Vandenabeele, P.; Liston, A.; Raes, J. Inflammation-associated enterotypes, host genotype, cage and inter-individual effects drive gut microbiota variation in common laboratory mice. Genome Biol. 2013, 14, R4. [CrossRef]

90. Parker, K.D.; Albeke, S.E.; Gigley, J.P.; Goldstein, A.M.; Ward, N.L. Microbiome Composition in Both Wild-Type and Disease Model Mice Is Heavily Influenced by Mouse Facility. Front. Microbiol. 2018, 9, 1598. [CrossRef]

91. Montonye, D.R.; Ericsson, A.C.; Busi, S.B.; Lutz, C.; Wardwell, K.; Franklin, C.L. Acclimation and Institutionalization of the Mouse Microbiota Following Transportation. Front. Microbiol. 2018, 9, 1085. [CrossRef] 
92. Rausch, P.; Basic, M.; Batra, A.; Bischoff, S.C.; Blaut, M.; Clavel, T.; Glasner, J.; Gopalakrishnan, S.; Grassl, G.A.; Gunther, C.; et al. Analysis of factors contributing to variation in the C57BL/6J fecal microbiota across German animal facilities. Int. J. Med. Microbiol. 2016, 306, 343-355. [CrossRef] [PubMed]

93. Laukens, D.; Brinkman, B.M.; Raes, J.; De Vos, M.; Vandenabeele, P. Heterogeneity of the gut microbiome in mice: Guidelines for optimizing experimental design. FEMS Microbiol. Rev. 2016, 40, 117-132. [CrossRef] [PubMed]

94. Sur, S.; Pal, D.; Mandal, S.; Roy, A.; Panda, C.K. Tea polyphenols epigallocatechin gallete and theaflavin restrict mouse liver carcinogenesis through modulation of self-renewal Wnt and hedgehog pathways. J. Nutr. Biochem. 2016, 27, 32-42. [CrossRef] [PubMed]

95. Yang, C.S.; Liao, J.; Yang, G.Y.; Lu, G. Inhibition of lung tumorigenesis by tea. Exp. Lung Res. 2005, 31, 135-144. [CrossRef] [PubMed]

96. Song, S.J.; Lauber, C.; Costello, E.K.; Lozupone, C.A.; Humphrey, G.; Berg-Lyons, D.; Caporaso, J.G.; Knights, D.; Clemente, J.C.; Nakielny, S.; et al. Cohabiting family members share microbiota with one another and with their dogs. eLife 2013, 2, e00458. [CrossRef] [PubMed]

97. Stahringer, S.S.; Clemente, J.C.; Corley, R.P.; Hewitt, J.; Knights, D.; Walters, W.A.; Knight, R.; Krauter, K.S. Nurture trumps nature in a longitudinal survey of salivary bacterial communities in twins from early adolescence to early adulthood. Genome Res. 2012, 22, 2146-2152. [CrossRef]

98. Hansen, T.H.; Kern, T.; Bak, E.G.; Kashani, A.; Allin, K.H.; Nielsen, T.; Hansen, T.; Pedersen, O. Impact of a vegan diet on the human salivary microbiota. Sci. Rep. 2018, 8, 5847. [CrossRef]

99. Wu, G.D.; Chen, J.; Hoffmann, C.; Bittinger, K.; Chen, Y.Y.; Keilbaugh, S.A.; Bewtra, M.; Knights, D.; Walters, W.A.; Knight, R.; et al. Linking long-term dietary patterns with gut microbial enterotypes. Science 2011, 334, 105-108. [CrossRef]

100. Frank, D.N.; Robertson, C.E.; Hamm, C.M.; Kpadeh, Z.; Zhang, T.; Chen, H.; Zhu, W.; Sartor, R.B.; Boedeker, E.C.; Harpaz, N.; et al. Disease phenotype and genotype are associated with shifts in intestinalassociated microbiota in inflammatory bowel diseases. Inflamm. Bowel Dis. 2011, 17, 179-184. [CrossRef]

101. Yamashita, Y.; Takeshita, T. The oral microbiome and human health. J. Oral Sci. 2017, 59, 201-206. [CrossRef]

102. Jackson, L.R.; Peterson, E.D.; McCoy, L.A.; Ju, C.; Zettler, M.; Baker, B.A.; Messenger, J.C.; Faries, D.E.; Effron, M.B.; Cohen, D.J.; et al. Impact of Proton Pump Inhibitor Use on the Comparative Effectiveness and Safety of Prasugrel Versus Clopidogrel: Insights from the Treatment with Adenosine Diphosphate Receptor Inhibitors: Longitudinal Assessment of Treatment Patterns and Events after Acute Coronary Syndrome (TRANSLATE-ACS) Study. J. Am. Heart Assoc. 2016, 5, e003824. [PubMed]

103. Seto, C.T.; Jeraldo, P.; Orenstein, R.; Chia, N.; DiBaise, J.K. Prolonged use of a proton pump inhibitor reduces microbial diversity: Implications for Clostridium difficile susceptibility. Microbiome 2014, 2, 1-11. [CrossRef] [PubMed]

104. Ho, C.K.; Choi, S.W.; Siu, P.M.; Benzie, I.F. Effects of single dose and regular intake of green tea (Camellia sinensis) on DNA damage, DNA repair, and heme oxygenase-1 expression in a randomized controlled human supplementation study. Mol. Nutr. Food Res. 2014, 58, 1379-1383. [CrossRef] [PubMed]

105. Liu, Z.; Bruins, M.E.; Ni, L.; Vincken, J.P. Green and Black Tea Phenolics: Bioavailability, Transformation by Colonic Microbiota, and Modulation of Colonic Microbiota. J. Agric. Food Chem. 2018, 66, 8469-8477. [CrossRef] [PubMed]

106. Landberg, R.; Manach, C.; Kerckhof, F.M.; Minihane, A.M.; Saleh, R.N.M.; De Roos, B.; Tomas-Barberan, F.; Morand, C.; Van de Wiele, T. Future prospects for dissecting inter-individual variability in the absorption, distribution and elimination of plant bioactives of relevance for cardiometabolic endpoints. Eur. J. Nutr. 2019, 58, 21-36. [CrossRef] [PubMed]

107. Li, F.; Wang, Y.; Li, D.; Chen, Y.; Qiao, X.; Fardous, R.; Lewandowski, A.; Liu, J.; Chan, T.H.; Dou, Q.P. Perspectives on the recent developments with green tea polyphenols in drug discovery. Expert Opin. Drug Discov. 2018, 13, 643-660.

Publisher's Note: MDPI stays neutral with regard to jurisdictional claims in published maps and institutional affiliations. 